\title{
A step towards water conservation in the state of Kuwait
}

\author{
M. Al-Senafy \& A. Al-Khalid \\ Water Resources Division, \\ Kuwait Institute for Scientific Research, Kuwait
}

\begin{abstract}
A campaign was conducted by the Kuwait Institute for Scientific Research (KISR) and funded by the Ministry of Electricity and Water (MEW) with a target of lowering the consumption of fresh water in the country by 20 million gallons per day and changing the water use culture of the society through reduction of waste and thus saving this important resource. The campaign, one of the biggest in Kuwait, involved the distribution of 1,100,000 faucet aerators to consumers in selected residential areas with high water consumption in addition to governmental authorities. The distributed aerators can save more than $40 \%$ of water consumption and sustain a constant flow of $6 \mathrm{l} / \mathrm{min}$ under a wide range of pressure The media campaign, that involved outdoor activities, TV and radio programs, news paper advertisements and articles, was used to highlight the responsibility of each consumer, the easy installation of the aerators and the benefits of using these water saving devices on the country, the society and the consumers. To improve public awareness, a call and a reception center were established, several seminars, public lectures, training courses, activities in the university and schools were arranged, in addition to the distribution of aerator packs embossed with water saving messages in exhibitions and shopping malls. Based on the reaction of the consumers, the availability of free installation and the experience gained in this project, $75 \%$ of the distributed aerators were expected to be installed with high level of confidence. This would save about Kuwaiti Dinars 15 million per year. Excellent reaction to and acceptance of the campaign by the consumers were encouraging and could be considered as the real success of this project. The outcomes of this project have proved that the option of saving water should have a priority in water resources management. Keywords: campaign, faucet aerators, awareness, consumers, saving, KISR.
\end{abstract}




\section{Introduction}

The demand for water continues to increase rapidly in Kuwait with an expanding population base and steep rise in per capita consumption. Reducing water consumption will avoid the costs for installation and operation of additional desalination utilities, and will delay costly investments in water systems which typically involve the expansion of water treatment, storage and distribution facilities. Conserving water includes the supply and the demand management methods. The supply management methods would include the network leakage/ loss control; use of special plumbing equipment; adoption of behavioral practices at users' end that conserve water; use of renovated wastewater for irrigation and other non-potable purposes; and water metering. The demand management methods should include pricing; information and education; water use regulations; and water use audits, Al-Senafy et al. [1]. Given the anticipated shortage in the supply of fresh water during the summer, it was necessary to take some quick steps to reduce water wastage and rationalizing consumption. To achieve the maintenance of water consumption at reasonable levels and on the basis of plans and strategies of the Ministry of Electricity and Water (MEW) for the rationalization of water consumption and to raise public awareness about the necessity of change in the current freshwater consumption patterns, a joint project between the MEW and the Kuwait Institute for Scientific Research (KISR) was planned. The aim of the project was to reduce the rate of fresh water consumption by about 20 million gallons per day through the distribution and installation of one million faucet aerators in the residential units in the areas of particularly high consumption, in addition to ministries, government institutions and private firms in the country. The project was requested and funded by MEW and executed by KISR Al-Senafy et al. [2]. It started in May 2007 and had a duration of 12 months. The main objectives of the project can be summarized as follows:

1. To distribute the water saving faucet aerators free of charge to residential units in the areas of high consumption in addition to the ministries, governmental institution and some private firms.

2. To reduce the daily consumption of fresh water by about $5 \%$, that is equivalent to about 20 million gallons.

3. To change the pattern and the culture of water consumption in the State of Kuwait.

\section{Technical specifications of aerators}

The technical specifications developed for the required faucet aerators aimed at high efficiency and the ability to save at least $40 \%$ of the quantities used without causing much difference to the consumer. The compensating faucet aerators selected are based on the technique of mixing water with air that delivers adequate water and ensures same amount of flow under different pressure. Furthermore, the inner component of the selected faucet aerators is made of 
plastic and the outer threaded housing is made of chromium, which extend the life span for many years. It also has the advantage of preventing the growth of bacteria that have adverse health effects on humans unlike many of the saving devices currently available in the market.

One million faucet aerators of water delivery capacity of $6 \mathrm{l} / \mathrm{min}$ and 100,000 plastic inserts of capacity $8 \mathrm{l} / \mathrm{min}$, to be used in the outdoor taps to minimize the consumption of water usage for gardening purposes, in addition to 100, 000 plastic key wrenches for installation of the aerators were requested. As soon as the requested devices were received from the supplier, these were packed in a way suitable for easy distribution. Each package contained six faucet aerators (6 $1 / \mathrm{min}$ ) with external thread, two faucet aerators $(6 \mathrm{l} / \mathrm{min})$ with internal thread, one plastic insert $(8 \mathrm{l} / \mathrm{min})$ for irrigation taps and one plastic key wrench for installation and dismantling of the distributed devices. The packets were stored in special warehouses established for this project and the forms for recording daily pick-up and distribution were prepared.

\section{Reception and call center}

The reception and the call center were established to provide a direct channel for easy communications between the public and the KISR team. The well trained teams explained the objectives of the project and steps to be followed for the installation of the faucet aerators. They also guided consumers how to ensure proper installation of the faucet aerators and to accrue benefits from them.

As this project addressed a vital issue directly linked to the consumption pattern of society, it was necessary to ensure the acceptability of the campaign by the consumers. Well trained specialized teams were formed through lectures and intensive technical training on how to deal scientifically with the consumers and distribution operations, in addition to advising the team members on acquiring necessary skills for receiving and dealing with varieties of people from the society at the reception center. The reception center also streamlined the delivery of the water saving devices to consumers who wished to have additional units, or was not covered by the distribution process as per the original plan.

\section{Methods of distribution}

Table 1 shows the residential areas covered by the distribution of faucet aerators and Table 2 shows the total number of faucet aerators that have been distributed through the activities of the project. A variety of ways and means was adopted in the distribution of the water saving devices to multiple segments, which can be identified as follows:

- Distribution to governmental agencies by KISR.

- Distribution in the residential areas by KISR.

- Distribution through the reception center by KISR.

- Distribution and installation of housing units by the cooperative societies. 
- Distribution in the Bayan area through the Tarsheed project.

- Distribution in shopping malls by KISR.

- Distribution to non-profit organizations and private firms by KISR.

- Distribution during the activities of the university, schools and exhibitions by KISR.

Table 3 presents the summary of expected installation of the faucet aerators, based on the information available to the project team and the best estimates arrived at from the consumer response and more than $75 \%$ of the total number of water saving devices distributed were installed.

Table 1: $\quad$ Residential areas covered by the campaign.

\begin{tabular}{|c|c|c|c|c|c|c|c|}
\hline No. & Area & $\begin{array}{c}\text { Residentia } \\
\text { I Units }\end{array}$ & $\begin{array}{c}\text { Faucet } \\
\text { Aerators }\end{array}$ & No. & Area & $\begin{array}{c}\text { Residentia } \\
\text { I Units }\end{array}$ & $\begin{array}{c}\text { Faucet } \\
\text { Aerators }\end{array}$ \\
\hline 1 & Al-Shuhada & 1237 & 11295 & 21 & Sawa & 3548 & 32274 \\
\hline 2 & Al-Salam & 1204 & 12897 & 22 & Al-Fintas & 304 & 2772 \\
\hline 3 & Hitteen & 1458 & 14418 & 23 & Al-Manqaf & 290 & 2610 \\
\hline 4 & Al-Aqila & 651 & 6048 & 24 & Al-Andalus & 2682 & 24552 \\
\hline 5 & Al-Zahraa & 1386 & 14166 & 25 & Al-Rihab & 1258 & 11709 \\
\hline 6 & Qurtuba & 2100 & 19638 & 26 & Sabah Al-Nassir & 1678 & 14796 \\
\hline 7 & Al-Yarmuk & 1223 & 11610 & 27 & Grinada & 450 & 4068 \\
\hline 8 & Abdulla Mubarak & 3684 & 35127 & 28 & Saad Al-Abdulla & 3018 & 27522 \\
\hline 9 & Mubarak Al-Abdulla & 931 & 8811 & 29 & Al-Naseem & 1319 & 11871 \\
\hline 10 & Hadya & 958 & 9909 & 30 & Ashbeelia & 467 & 4203 \\
\hline 11 & Al-Qurain & 2559 & 24210 & 31 & Al-Rawda & 998 & 14850 \\
\hline 12 & Al-Addan & 3544 & 32166 & 32 & $\begin{array}{l}\text { A. Al-Salem and } \\
\text { Mansouria }\end{array}$ & 598 & 7290 \\
\hline 13 & Mubarak Al-Kabeer & 3490 & 31599 & 33 & Al-Faiha & 427 & 8460 \\
\hline 14 & Al-Qusoor & 2972 & 27153 & 34 & Al-Adailyia & 760 & 9180 \\
\hline 15 & Sabah Al-Salem & 5392 & 49014 & 35 & Al-Khaldiya & 449 & 10350 \\
\hline 16 & Ali Sabah Al-Salim & 3818 & 34389 & 36 & Al-Aediya & 488 & 8270 \\
\hline 17 & Mishref & 2145 & 19494 & 37 & Al-Nuzha & 569 & 9000 \\
\hline 18 & Al-Na'eem & 601 & 5418 & 38 & Jeleeb Al-Shuyokh & 694 & 9000 \\
\hline 19 & Al-Surra & 1966 & 17982 & 39 & Al-Jabria & 237 & 3600 \\
\hline 20 & Al-Qairawan & 697 & 6480 & 40 & Bayan & 1546 & 27000 \\
\hline \multicolumn{2}{|c|}{ Total Residential Units } & \multicolumn{2}{|c|}{63,796} & \multicolumn{2}{|c|}{ Total Faucet Aerators } & \multicolumn{2}{|c|}{635,200} \\
\hline
\end{tabular}


Table 2: Total number of distributed faucet aerators within the project activities.

\begin{tabular}{|c|c|c|}
\hline Distribution Method & $\begin{array}{c}\text { Residential } \\
\text { Units }\end{array}$ & $\begin{array}{c}\text { Total of Faucet } \\
\text { Aerators }\end{array}$ \\
\hline Distribution to the residential areas & 63,796 & 635,200 \\
\hline Distribution through project reception center & 11,432 & 152,154 \\
\hline Subtotal & $\mathbf{7 5 , 2 2 8}$ & $\mathbf{7 8 7 , 3 5 4}$ \\
\hline Distribution to governmental agencies & - & 279,600 \\
\hline Distribution to non-profit organizations and private firms & - & 5,776 \\
\hline $\begin{array}{c}\text { Distribution during the activities of the university, schools } \\
\text { and exhibitions }\end{array}$ & - & 22,000 \\
\hline Distribution in shopping malls & - & 5,517 \\
\hline Total Distributed Faucet Aerators & $\mathbf{1 , 1 0 0 , 2 4 7}$ \\
\hline
\end{tabular}

Table 3: $\quad$ Summary of the expected installation of saving Aerators.

\begin{tabular}{|c|c|c|c|c|}
\hline Category & Description & $\begin{array}{c}\text { Distributed } \\
\text { Aerators }\end{array}$ & $\begin{array}{c}\text { Expected } \\
\text { Installation } \\
\mathbf{\%}\end{array}$ & $\begin{array}{c}\text { Expected } \\
\text { installed } \\
\text { Aerators }\end{array}$ \\
\hline First & $\begin{array}{c}\text { Governmental agencies, } \\
\text { non-profit organizations, } \\
\text { private firms and } \\
\text { reception center }\end{array}$ & 437,530 & 95 & 415,654 \\
\hline Second & $\begin{array}{c}\text { Free distribution and } \\
\text { installation by the } \\
\text { cooperative societies }\end{array}$ & 80,000 & 90 & 72,000 \\
\hline Third & $\begin{array}{c}\text { KISR distribution and } \\
\text { Free installation by the } \\
\text { cooperative societies }\end{array}$ & 229,004 & 80 & 183,203 \\
\hline Fourth & Distribution only & 353,713 & 50 & 176,857 \\
\hline \multicolumn{2}{|c|}{ Total } & $\mathbf{1 , 1 0 0 , 2 4 7}$ & $\mathbf{7 7}$ & $\mathbf{8 4 7 , 7 1 3}$ \\
\hline
\end{tabular}

\section{Public awareness}

The project took into consideration the possibility that consumers might not accept the idea of replacing the existing faucet in the residential units. To circumvent this possibility, one of the steps undertaken was to convince the consumers about the benefits of these aerators and to highlight the benefits of the rationalization of water consumption that these devices would achieve through an information campaign having components as follows:

1. Logo design project

2. Project publications

3. Outdoor media campaign 
4. Radio and television presentations

5. Newspaper advertisements

6. Newspaper articles

7. Press conferences.

The public awareness campaign emphasized the economic aspects of water saving, the best methods for water use rationalization that can be easily practiced by the consumers and methods to be followed in the installation and use of the water saving devices. The project involved many events and activities such as participation in World Water Day organized by MEW and the accompanying exhibition, participation in the Open Day for the management of water resources organized by KISR, arrangement of training courses for school students and delivery of lectures and demonstration of water saving activities in the university, schools and residential areas. To widen the circle of contact with the public, the project covered the markets and shopping malls with similar activities including the distribution of the water saving devices.

\section{Discussion and conclusion}

The growing demand for water in Kuwait at its current rate is expected to double its production need to four times the current production at year 2025 . Investments in efforts directed towards the lowering of water consumption will, therefore, result in a high return and fall in the category of a strategic option. By looking at the consumption of freshwater in the State of Kuwait, it is clear that $85 \%$ of consumption is for domestic use. A study conducted by KISR has found that approximately $53 \%$ of the total consumption in a residential unit is delivered through taps. Since the distribution and installation of the aerator faucets through the current scheme has covered about $30 \%$ of residential units in Kuwait, and as these devices are delivering not less than $40 \%$ of water consumed, it should translate into savings of at least $5 \%$ of the total daily fresh water consumption in Kuwait, which is equivalent to a saving of Kuwaiti Dinars 15 million annually. The amount is expected to cover the expenses of the project within a period not exceeding twenty days in the event all the distributed devices have been properly installed.

Based on the above, it has been concluded that the investment in the project would be recovered within a maximum period of 30 days. In fact, the response from the consumers was tremendous.

The project has achieved its objectives and this should encourage the extension of the campaign to cover all areas and sectors of domestic consumption in Kuwait. A physical verification of the outcome of the project is also needed to be undertaken in coordination with MEW by monitoring water consumption, both at the district level and at the level of individual consumer. After 6 months from the date of the project completion, MEW has conducted a primary questionnaire survey on random consumers at areas that were covered by the project and it has been found that about $21 \%$ of the consumers have experienced a substantial reduction in their freshwater bills. 


\section{References}

[1] Mohamed Al-Senafy, Al-Khalid, A., Mukhopadhyay, A., and Al-Fahad, K. 2008a. Outlines for Water Saving Practices in Kuwait. Proc. of the $8^{\text {th }}$ Gulf Water Conference Water in the GCC Towards an Optimal Planning and Economic Perspective, Bahrain 3-6 March, 2008, KISR8890, Kuwait.

[2] Mohamed Al-Senafy, Al-Khalid, A., Al-Fahad, K. and Marzouk, F. 2008b. Distribution of Water Saving Aerators in the State of Kuwait. Kuwait Institute for Scientific Research, Report No. KISR9263, June 2008, Kuwait. 